\title{
MULTIPLE SCLEROSIS: NEW ASPECTS OF IMMUNOPATHOGENESIS
}

\author{
Ines Lazibat ${ }^{1,2}$, Maja Rubinić Majdak ${ }^{2}$ and Sven Županić ${ }^{2}$ \\ ${ }^{1}$ Faculty of Medicine, Josip Juraj Strossmayer University of Osijek, Osijek, Croatia; \\ ${ }^{2}$ Dubrava University Hospital, Zagreb, Croatia
}

\begin{abstract}
SUMMARY - Multiple sclerosis (MS) is a multicomponent disease characterized by inflammation, neurodegeneration, and cancellation of the central nervous system recovery mechanisms. The cause of MS is still unknown, but it is undeniable that genetic, environmental and immune factors are involved in the etiopathogenesis of this complex and heterogeneous disease. From the aspect of immunopathogenesis, until recently the opinion prevailed that autoreactive $T$ lymphocytes played a major role, the activation of which is a key step in MS. The knowledge of the effector and regulatory roles of $\mathrm{B}$ cells supports a new concept of MS immunopathogenesis that is based on the highly complex interaction of $\mathrm{T}$ and $\mathrm{B}$ cells, with $\mathrm{B}$ cells actively participating in cellular immunity by directing the intensity and quality of cellular immune response. The mechanisms of B cell activity in MS immunopathogenesis are multiple and include antigen presentation and $\mathrm{T}$ cell costimulation, cytokine secretion, antibody synthesis, and formation of ectopic lymphoid B cell aggregates in the intrameningeal spaces. The importance of B cells has been confirmed by modern therapeutic options for the treatment of MS.
\end{abstract}

Key words: Multiple Sclerosis; Inflammation; T-Lymphocytes; B-Lymphocytes; Immunity, Cellular

\section{Pathogenesis of Multiple Sclerosis}

Multiple sclerosis (MS) is an idiopathic chronic inflammatory demyelinating disease of the central nervous system (CNS) the leading features of which are numerous demyelinating lesions known as plaques. MS was named after gliotic sclerozation of the lesions that appear during disease progression.

\section{Risk Factors for Multiple Sclerosis - Genetic or Environmental Factors?}

The cause of MS is still unknown. It is suspected that MS is a multicomponent disease mediated by the infection-induced autoimmune process superimposed on genetic predisposition. Thus, the interaction of

Correspondence to: Assist. Prof. Ines Lazibat, MD, PhD, Department of Neurology, Dubrava University Hospital, Av. Gojka Suška 6, HR-10000 Zagreb, Croatia

E-mail: ilazibat@kbd.hr

Received March 1, 2018, accepted May 21, 2018 genetic, environmental and immune factors is involved in the etiopathogenesis of this complex and heterogeneous disease. Research has shown that environmental factors play a significant role in the pathogenesis of MS, including infections, especially Epstein-Barr virus (EBV), sun exposure, decreased vitamin D plasma levels, smoking, obesity and increased salt intake, although a fully clarified causeand-effect relationship has not yet been proven. There is, however, substantial evidence for autoimmune pathogenesis of MS. The proposed pathogenesis of MS is characterized by the migration of peripheral $\mathrm{T}$ and $\mathrm{B}$ cells in the CNS, where they react to one or more unidentified myelin or neuronal antigens, and stimulate and maintain an inflammatory process that causes demyelination, axon loss and end of neuronal dehydration ${ }^{1}$.

The role of EBV in the development of MS is not sufficiently investigated, but there is convincing evidence for latent EBV infection re-activation initiating an autoimmune cascade in MS. 
Geographic variations in the incidence of MS can partially be explained by genetic factors. The influence of genetic factors in MS is confirmed by 20 to 40 times higher prevalence among patients' first-degree relatives than in the general population.

Multiple sclerosis is not a hereditary disease, although individuals exhibit polygenetic predisposition linked to HLA locus on 6p 21 chromosome involving polymorphism of DR2 gene. Recent studies have shown that variations in DR1 complex, as well as HLA-C genome, could affect the likelihood of MS. These discoveries are associated with MS 'risk' genes discovered in the latest analysis of experimental autoimmune encephalomyelitis, which show that for 9 different genes associated with MS (MS gene susceptibility), Bach 2, IL2ra, Irf8, Merkk, Odf3b, Plek, Rgs1, Slc30a7 and Thada confirmation can be made about their differential regulation in pathogenic CD4 T cells. This finding confirms the inclusion of MS 'risk' genes in the pathophysiology in the animal model and exposes additional inflammatory networks important for the development of the disease.

When known environmental factors such as exposure to EBV infection and smoking are added to genetic risk, a score can be obtained that can partially predict the risk of developing $\mathrm{MS}$ and demonstrate consistent discrimination in independent samples. However, such a score cannot yet predict the risk of conversion from clinically isolated syndrome to clinically definite MS.

\section{Immunopathogenesis of Multiple Sclerosis}

The current concept of the pathogenesis of MS involves the activation of potentially autoreactive CD4+ T lymphocytes as an initial and key event in its pathogenesis. Activated autoreactive $\mathrm{T}$ lymphocytes express on their surface adhesive molecules that enable them to bind to the endothelium-brain barrier (EBB). At the same time, activated $\mathrm{T}$ lymphocytes produce matrix metalloproteinase (MMP) enzymes that allow the creation of openings in EBB, thereby disrupting its semipermeability and consequently enabling activation of activated T lymphocytes in the cerebral parenchyma. When such lymphocytes within the CNS meet the myelin basic protein (MBP) presented by the microglia in the role of the antigen presenting cells of the CNS, the autoreactive $\mathrm{T}$ lymphocytes are reactivated and

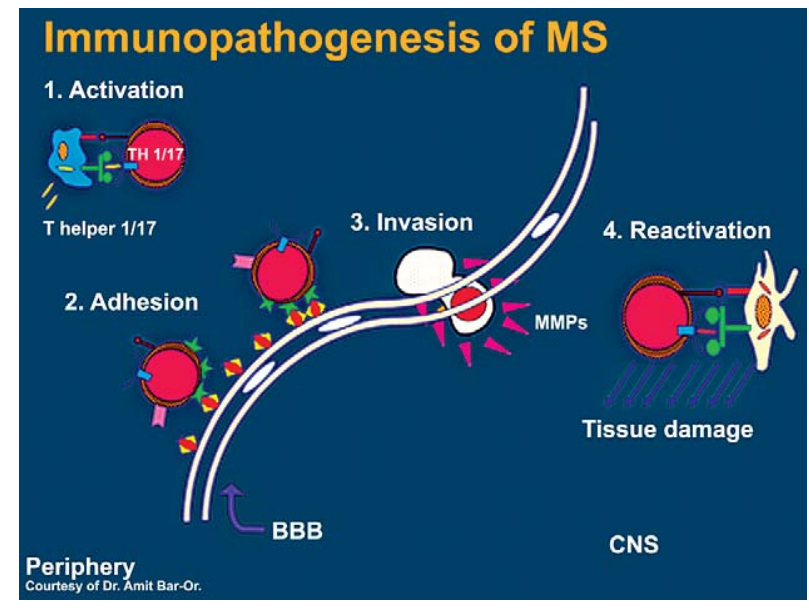

Fig. 1. The concept of immunopathogenesis of multiple sclerosis.

initiate the secretion of proinflammatory cytokines that contribute to further deterioration of the semipermeability of EBB and determine the formation of inflammatory lesions ${ }^{1,2}$ (Fig. 1).

Thus, the activation of autoreactive peripheral $\mathrm{T}$ lymphocytes is an initial event in the pathogenesis of MS. Simultaneously, it is a sort of enigma that has yet to be clarified since there is still no answer to the question of why the activation of autoreactive $\mathrm{T}$ lymphocytes is possible at all. One of the key activating factors is the recognition of certain antigens on the surface of the antigen presenting cells (APC) that provide the necessary costimulation of $\mathrm{T}$ lymphocytes by providing a costimulatory signal. It is believed that most of these antigens are in the form of viral peptides, such as peptides derived from human herpes virus 6 (HHV6), EBV, and Chlamydia pneumoniae. Peptide fragments of these microorganisms activate autoreactive $T$ lymphocytes specific to myelin basic protein (MBP), the most represented protein of the myelinic envelope via two mechanisms:

- molecular mimicry, and

- damaging functional anergy in the inflammatory environment

For peripheral $\mathrm{T}$ lymphocyte activation, gene constitution of a person that is associated with HLA-DR2, DR15 and other DR molecules believed to contribute to molecular mimicry between virus and MBP peptides is also significant ${ }^{3}$.

Inflammatory lesion pathognomonic to MS is demyelinating plaque. The formation of plaque begins 


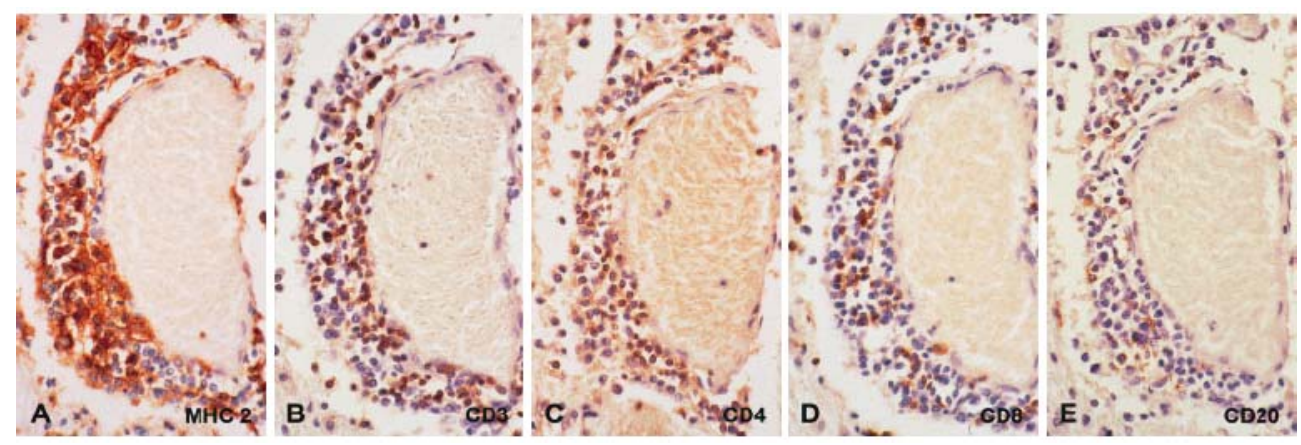

Fig. 2. Multiple sclerosis lesions (demyelinating plaques) are characterized by accumulation of inflammatory mononuclear cells, primarily $T$ and $B$ cells, which infiltrate perivascular spaces and surrounding white matter.

with the accumulation of inflammatory mononuclear cells that infiltrate perivascular spaces and the surrounding white matter. Analysis of this inflammatory infiltrate has shown it to consist primarily of $\mathrm{T}$ and $\mathrm{B}$ cells. Importantly, however, the lymphocytic infiltration does not affect the entire cerebral parenchyma but only in certain sites where the demyelinating plaque may be caused, although MBP is widely present. It is known that localization of lesions in MS may be extremely variable and is a very important factor that determines clinical presentation of the disease. The difference in the distribution of lesions among MS patients is another puzzle of the disease attributed to gene constitution of the patient (Fig. 2).

In the demyelinating plaque, apart from demyelinization, axonal damage and oligodendrocyte destruction also occur through numerous processes involving free radicals, direct complement depletion, antibody complement activation, natural-killer cell (NKC) mediated cytotoxicity, myelin phagocytosis, protease secretion and oligodendrocyte apoptosis.

All effector mechanisms of the immune system are practically involved in the process of demyelinating plaque formation in MS, and it is considered that all of

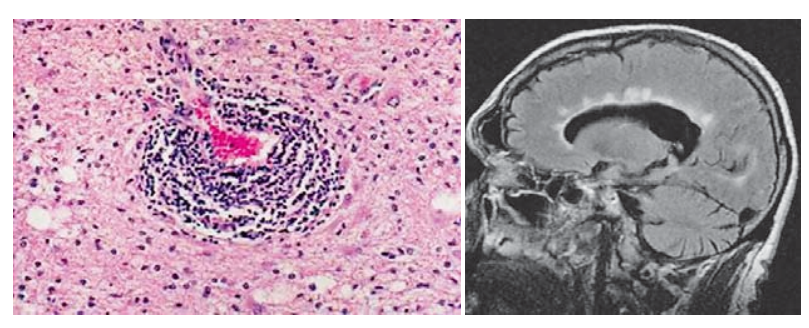

Fig. 3. Demyelinating plaques. them are primarily orchestrated by autoreactive CD4+ T lymphocytes (Fig. 3).

These inflammatory events in MS relapse on average last from several days to two weeks. Residual cells and oligodendrocyte precursors that are still present in the adult CNS are afterwards activated and remyelination of the unmyelinated axons begins, although the thickness of the newly formed myelin sheath can never be fully restored, causing the remyelinized fibers to have slower conductivity of the nerve pulse compared to intact fibers. Additionally, restored myelin sheath also differs in composition because it contains certain isoforms of MBP considered to be functionally insufficient and vulnerable to inflammation.

Many abnormalities in the functioning of the immune system exist in MS, but the opinion that autoreactive T lymphocytes play the key role in MS pathogenesis predominated until recently. Lately, the concept of MS as an autoimmune disease mediated mostly by $T$ reactive cells has been questioned primarily due to some key findings related to $\mathrm{B}$ cells. The immunopathogenesis of MS was determined by an extremely complex interaction of $\mathrm{T}$ and $\mathrm{B}$ cells during which both types of cells actively participated in the pathogenic process.

As for the role of $\mathrm{T}$ lymphocytes, for more than thirty years, the finding has been known that CD4+ T lymphocytes after stimulation by antigen may be differentiated into two major subpopulations with a clearly defined cytokine secretion profile. These are Th1 and Th 2 cells. Th1 cells are primarily produced by interferon- $\gamma(\mathrm{IFN}-\gamma)$, which acts as the most potent macrophage activator in cellular immunity. The 


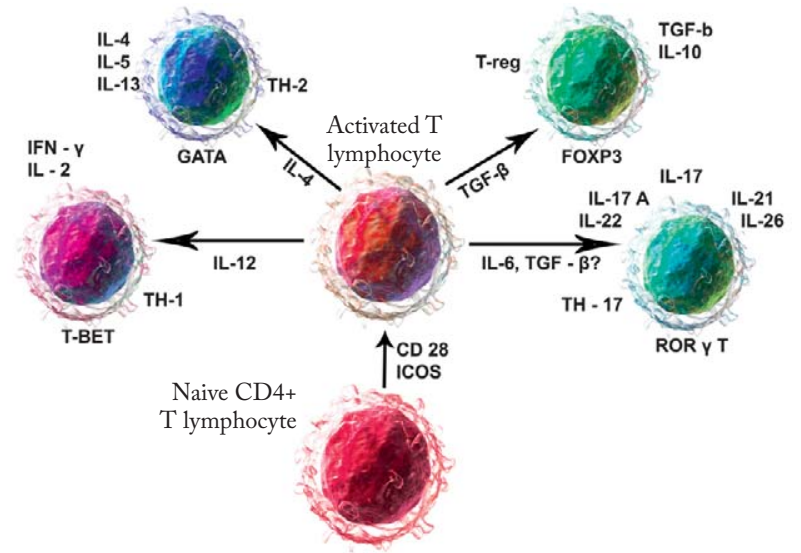

Fig. 4. T-cell profiles involved in multiple sclerosis.

hypothesis that Th1 cells play a major role in MS pathogenesis was prevalent at first, but it was questioned with the discovery of $\mathrm{T}$ regulatory cells (the function of which is maintaining homeostasis in the immune system), and in particular Th17 cells as a completely recently found subpopulation of CD4+ T discovered about ten years ago ${ }^{5,6}$ (Fig. 4).

Cytokine secretion of Th17 cells is extremely polymorphic. The basic cytokine is interleukin 17 (IL-17), which is a highly potent proinflammatory cytokine that acts through its own IL-17 receptors of ubiquitous tissue distribution.

In the animal model of MS, experimental autoimmune encephalomyelitis (EAE), it has been demonstrated that TH17 cells are carriers of the inflammatory process in MS, while Th1 cells have a protective role, which contrasts the present concept of MS pathogenesis. The ratio between Th17 and Th1 cells determines whether the initiation of inflammation and consequently formation of demyelinating plaques will occur. The inflammation occurs when the ratio between Th17 and Th1 is greater than 1 because there is a disproportionate increase in the secretion of IL-17, which is at present considered to be the main mediator of autoimmune processes in the $\mathrm{CNS}^{7}$.

Intriguingly, in the spinal cord, the inflammation occurs when the relationship between Th17 and Th1 cells is less than 1 , indicating that the main mediator of inflammation in the spinal cord are Th1 cells. The reasons for this paradoxical pathogenic process of autoimmunity in the brain and spinal cord are still unclear.
A recent discovery of MS pathogenesis is functional antagonism between Th17 and T regulatory cells. Th17 cells are highly proinflammatory, while $\mathrm{T}$ regulatory cells are immunosuppressive, i.e. immunotolerant, although, interestingly, both use the same factors of differentiation, i.e. transforming growth factor $\beta$ (TGF- $\beta$ ) and interleukin 6 (IL-6). The involvement of TGF- $\beta$ in the Th17 cell differentiation process was surprising since TGF- $\beta$ alone has antiinflammatory properties and induces activation of FOXP3 transcription factor, an essential factor for the generation of $\mathrm{T}$ regulatory lymphocytes. However, when found in the inflammatory environment, near the proinflammatory cytokine IL- 6 , TGF- $\beta$ changes functional characteristics and acts synergistically inducing Th17 cell formation in a proinflammatory way $^{8}$ (Fig. 5).

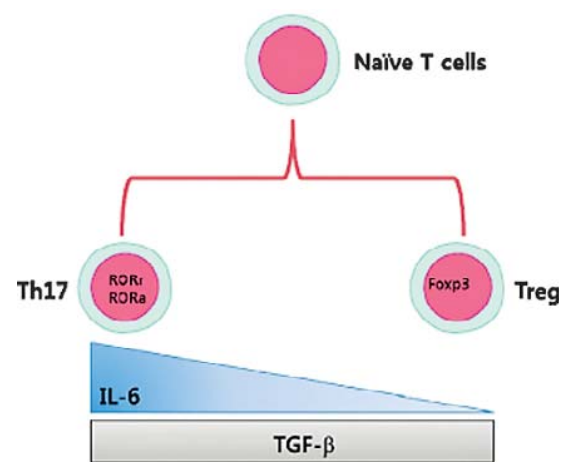

Fig. 5. Functional antagonism between $T h 17$ and T regulatory cells.

For the activation of $\mathrm{T}$ lymphocytes, interaction with $\mathrm{B}$ cells that have the role of antigen presenting cells producing the costimulatory signals/molecules crucial for the activation of T lymphocytes is necessary. It is, however, important to point out that the interaction between $\mathrm{T}$ and $\mathrm{B}$ lymphocytes is direct, since it is accomplished through costimulatory molecules producing B lymphocytes, and two-way, since $\mathrm{B}$ lymphocytes provide $\mathrm{T}$ lymphocytes with costimulatory signal by means of antigen presentation (costimulatory molecules determine the extent of $\mathrm{T}$ lymphocyte expansion after activation), while $T$ lymphocytes affect B cells via cytokines and surface ligands $s^{9,10}$. The previously mentioned interaction has the potential for positive feedback and circulus vitiosus creation. The question remains which of these cells 


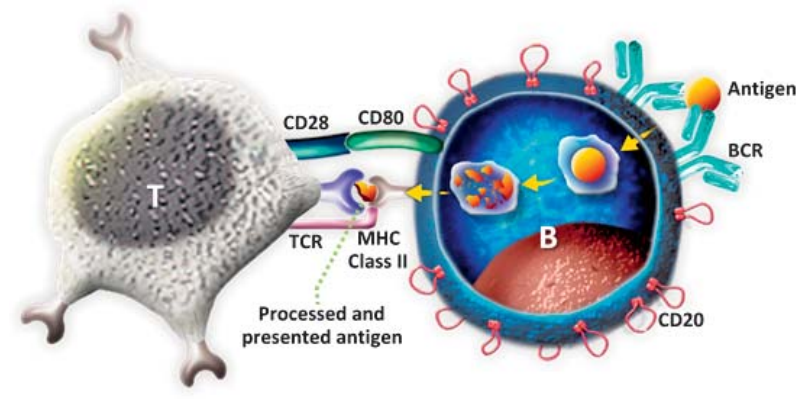

Fig. 6. Interaction with B cells is crucial for Tcell activation (antigen-presenting cells).

makes the crucial mistake of triggering the autoimmune process (Fig. 6).

\section{The Role of B Cells in Multiple Sclerosis Pathogenesis}

The B cells are carriers of humoral immunity. Their role in modulation of the immune response is very complex and goes beyond the limits of humoral immunity. They play an important role in the development and regulation of cellular immunity, and this does not imply only passive interaction with $T$ cells. The B cells, with their regulatory and effector role, actively participate in cellular immunity, thus directing the intensity and quality of the cellular immune response.

One of the hypotheses of autoimmunity is generally the loss of immune tolerance. In MS patients, it is considered that there is a specific deficit of the peripheral B cell immune tolerance, which contributes to the accumulation of autoreactive $\mathrm{B}$ cells in peripheral blood. The formation of autoreactive B cells is relatively common in healthy subjects, but in healthy subjects, unlike MS patients, the autoreactive $\mathrm{B}$ cells are removed and their accumulation does not escalate. Removal is done in two ways:

- on the periphery where autoreactive B cells are selected and removed prior to differentiation into mature cellular forms; and

- in bone marrow where B cell clones that have expressed self-reactive antibodies are removed.

This removal procedure of autoreactive B cells is absent in MS patients due to the loss of immune tolerance, resulting in their accumulation in peripheral blood.

The mechanism of action of $\mathrm{B}$ cells is multiple:

- presentation of antigen and costimulation of $\mathrm{T}$ cells,

- cytokine secretion,

- antibody production, and

- ectopic neolymphogenesis - implying the formation of ectopic lymphoid structures similar to follicles in intrameningeal spaces (Fig. 7).

Although the dominant role of $\mathrm{T}$ cells in MS pathogenesis is often stressed, B cells can contribute to the pathogenesis of MS in various ways, e.g., as antigen presenting cells that costimulate autoreactive $\mathrm{T}$ cells, as a source of autoantibodies to different components of myelin, axon and neurons, which contributes to demyelination and axonal damage. Further, they serve as regulatory cells that secrete cytokines and thus affect

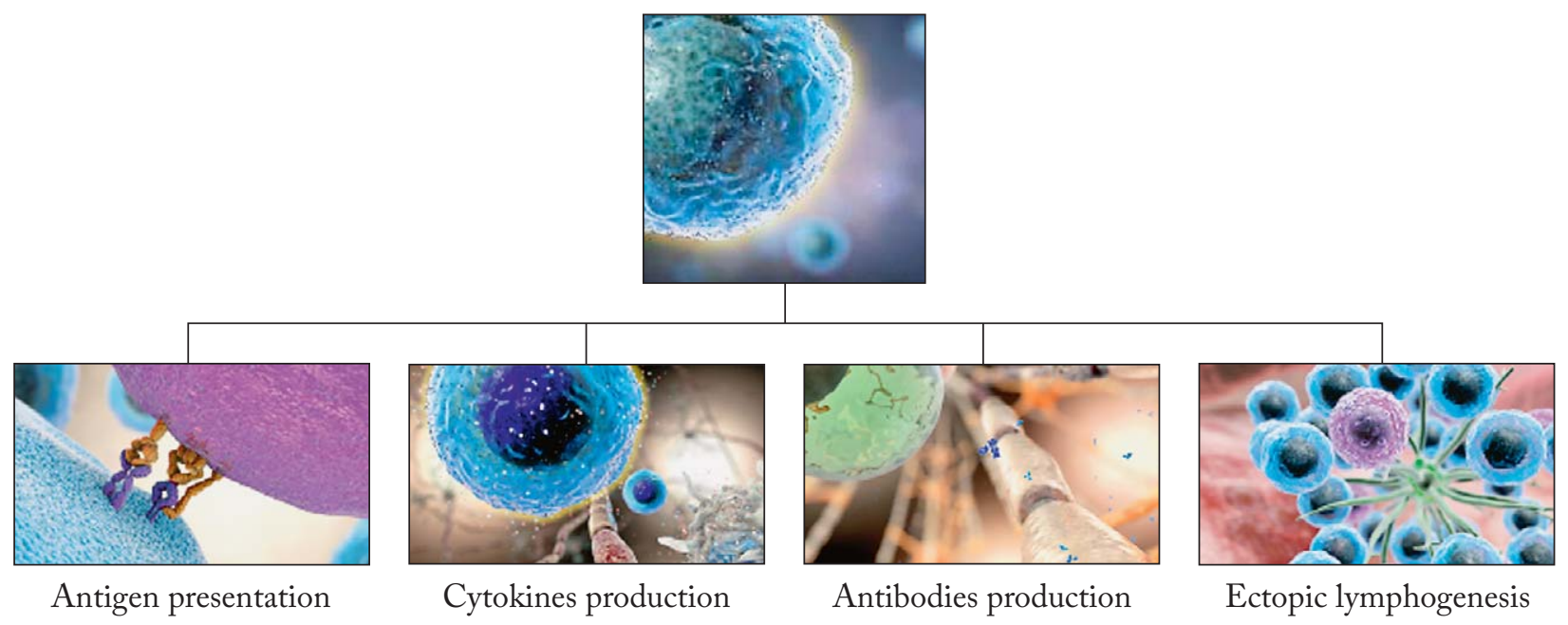

Fig. 7. Multiple roles of B cells in multiple sclerosis pathophysiology. 


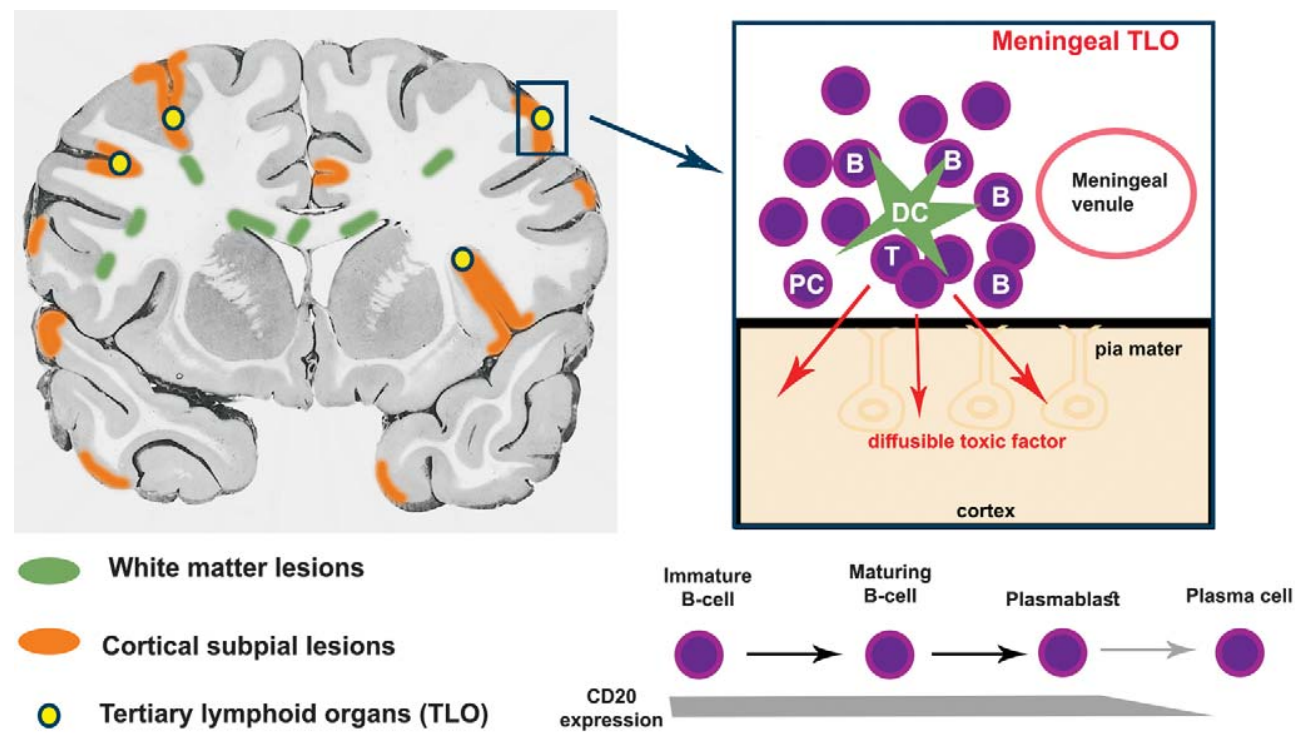

Fig. 8. Ectopic B cell aggregates are often seen near first cortical layer in multiple sclerosis patients with progressive form of the disease.

the activity of regulatory $\mathrm{T}$ cells by modulating $\mathrm{T}$ cell response. There is another important role of $\mathrm{B}$ cells, and it is ectopic neolymphogenesis, which implies the formation of ectopic lymphoid structures similar to follicles found in the meninges of MS patients, called tertiary lymph nodes and containing $\mathrm{B}$ cells and plasma cells. It is believed that these intrameningeal follicles can be the source of latent EBV infection the potential role of which in MS development is not sufficiently researched, but there is some evidence that repeating latent $\mathrm{EBV}$ infection might trigger the autoimmune cascade ${ }^{11-15}$.

\section{Production of Antibodies}

The presence of antibodies in the cerebrospinal fluid (CSF) of MS patients is convincing evidence that $\mathrm{B}$ cells are involved in MS pathogenesis. In healthy individuals, antibodies are not synthesized within CNS; therefore, their presence in the CSF always refers to an autoimmune process. The synthesis of antibodies is in the domain of effector function of the B cells, which, upon differentiation into plasma cells, are responsible for the production of antibodies. The intrathecal synthesis and presence of $\mathrm{IgG}$ in CSF of MS patients was first demonstrated by electrophoresis in 1942. Although they represent the 'gold standard' in MS diagnosis, oligoclonal bands (OCB) are not

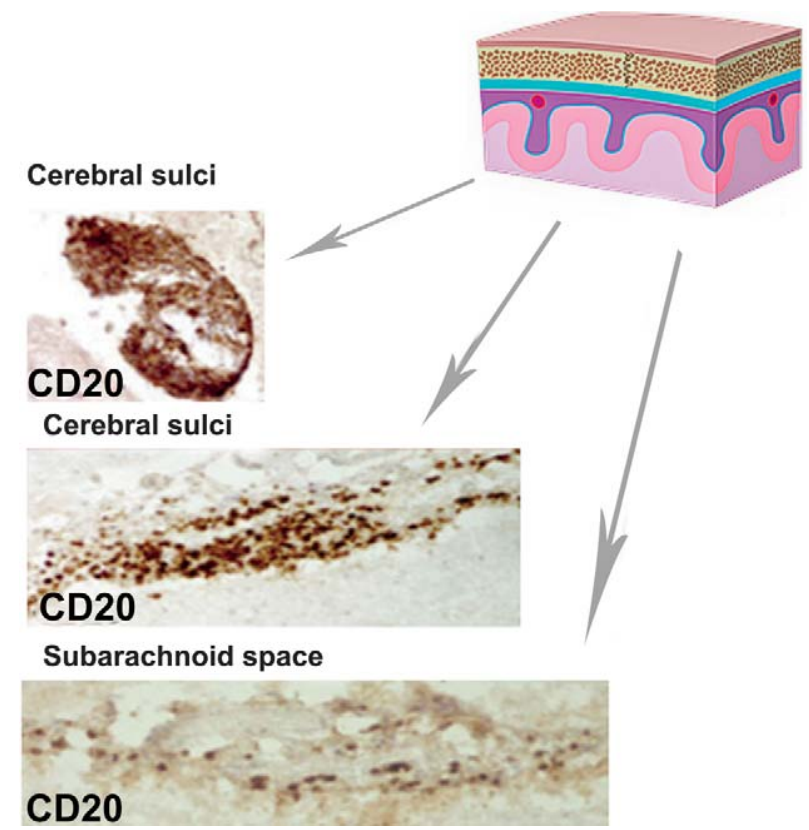

Fig. 9. Subpial areas of demyelination with ectopic B cell aggregates.

specific for MS. Their presence can also be found in infectious CNS diseases such as neuroborreliosis, herpes simplex encephalitis, HIV infection and subacute sclerosing panencephalitis. However, OCB in MS patients are a persistent finding (once proved forever present), while in other entities they are often a 


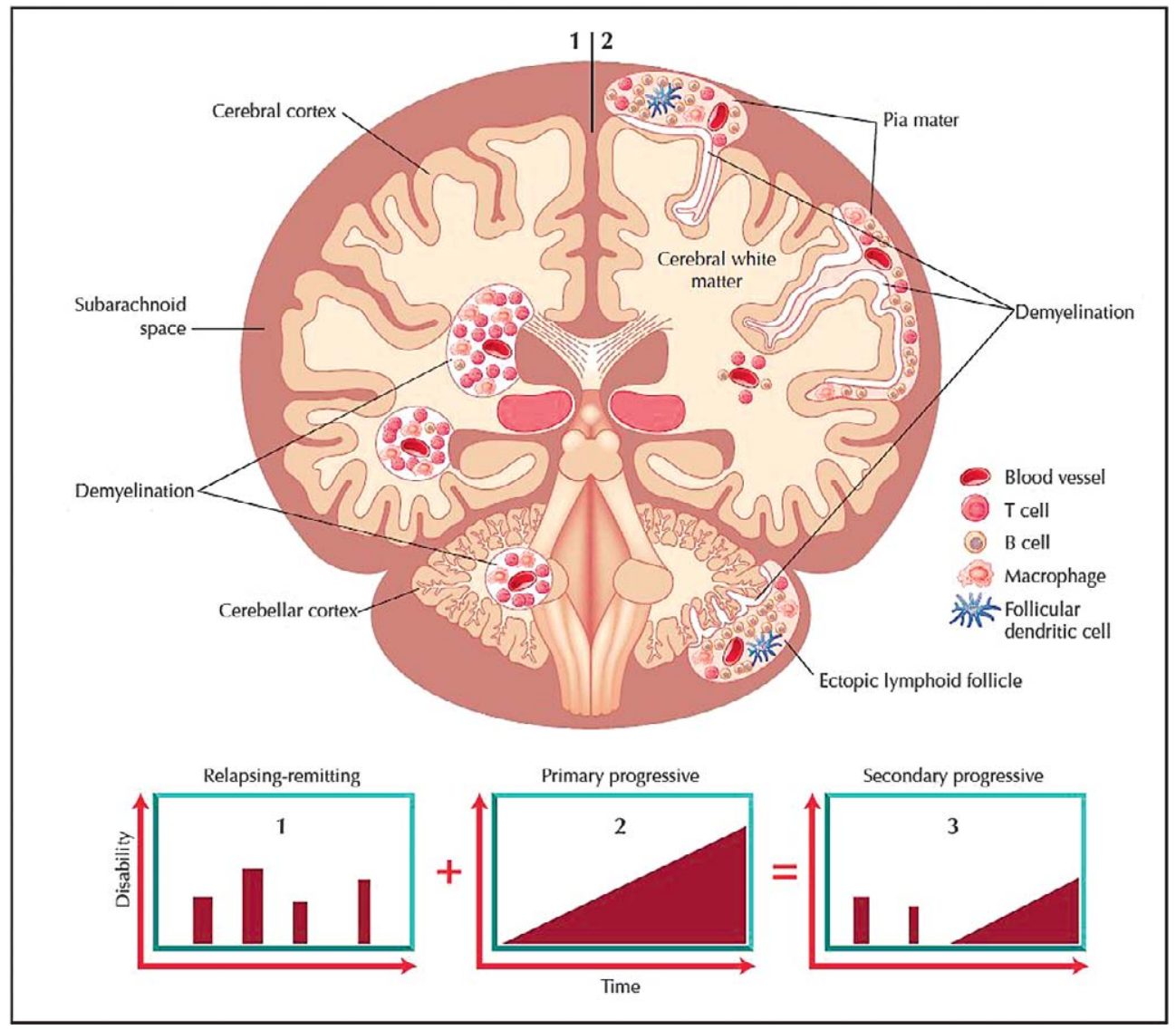

Fig. 10. Immunopathologic substrate in multiple sclerosis includes focal and diffuse distributions of pathologic changes.

transitory phenomenon and mostly disappear after several weeks or months. The presence of two or more bands in the CSF and their simultaneous absence in the serum strongly supports the diagnosis of MS.

Studies have shown that OCB pattern differs among patients, suggesting that there is a specific $\mathrm{B}$ cell response in MS patients that is unique to each individual patient.

Although OCB and intrathecal antibody synthesis have been subject to numerous studies, their significance in the pathogenesis, as well as their specificity, or target autoantigens, have not yet been precisely defined. Among the autoantibodies which play a role in MS pathogenesis, most important are proteins involved in the composition of the myelin sheath, i.e. myelin basic protein (MBP), myelin oligodendrocyte glycoprotein (MOG), myelin proteolipid protein (PLP) and myelin-associated protein (MAG).

\section{Multiple Sclerosis and Epstein-Barr Virus - Subpial Cortical Pathology}

Multiple sclerosis is often associated with EBV infection. Previous infectious mononucleosis caused by $\mathrm{EBV}$ increases the risk of MS development. It is believed that repeated reactivation of latent EBV infection might be a trigger for starting an autoimmune cascade. Studies have found that the source of latent EBV infection may be ectopic aggregates of $\mathrm{B}$ cellular follicles, so called ectopic tertiary lymphoid tissues (TLT) in the intrameningeal spaces.

The presence of ectopic B cellular follicles is an adverse prognostic factor because it is associated with an unfavorable outcome of the disease in terms of faster progression and faster development of disability. Patients with positive ectopic B cellular follicles before 50 years of age develop severe disability that implies dependence on wheelchairs (Figs. 8 and 9). 


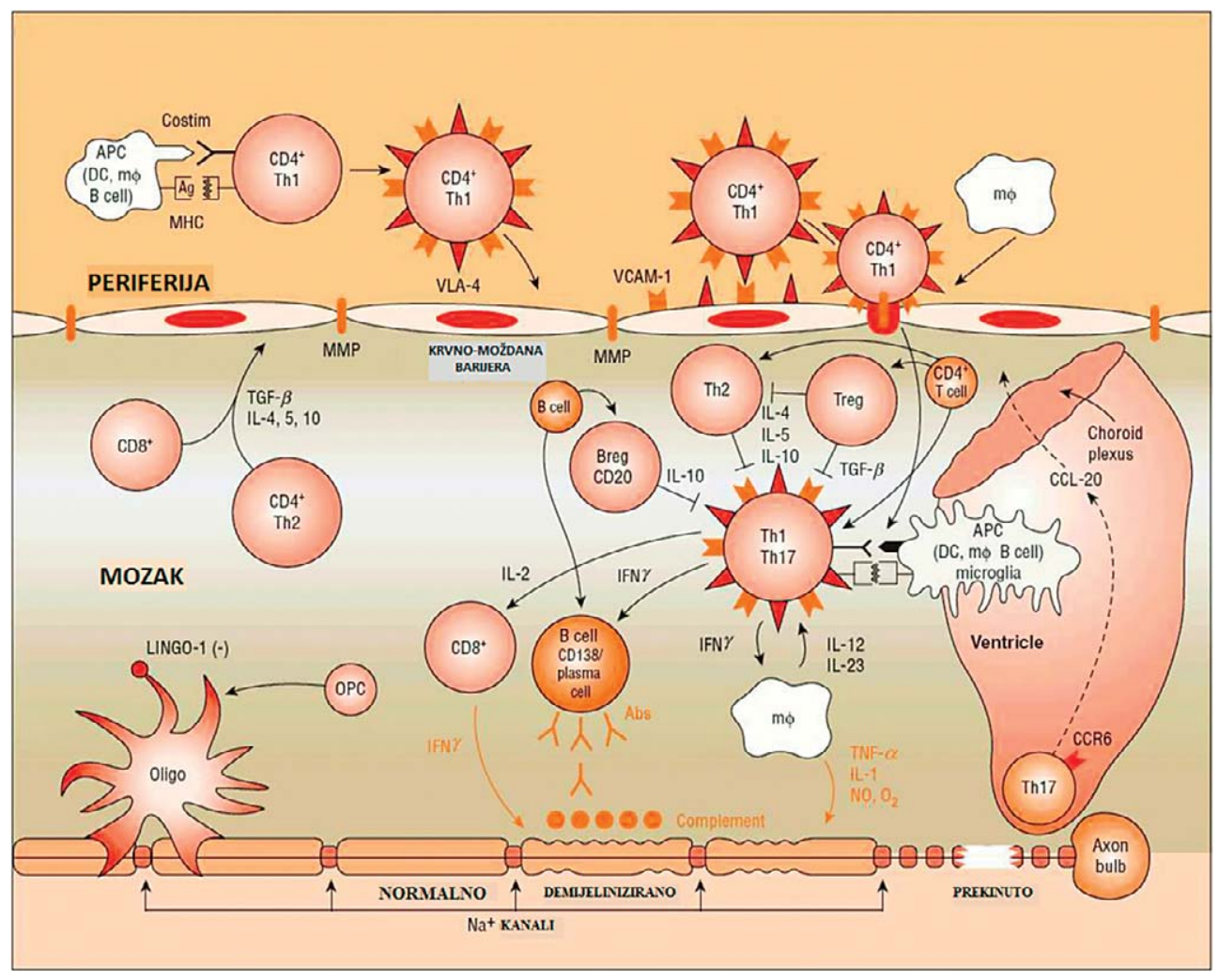

Fig. 11. Autoimmune theory of multiple sclerosis pathogenesis.

Multiple sclerosis was once considered a white matter disease, which is only partially true. Today we know that the immunopathologic substrate in MS includes focal and diffuse changes affecting both the white and the gray matter. In addition to focal demyelination, pathologic changes in MS also imply significant changes in the white and gray matter not affected by plaques (normal appearing white matter (NAWM) and normal appearing gray matter (NAGM)), then axonal damage and loss of neurons and atrophy of the brain, which is now considered an important predictor of permanent disability of the patient.

It is important to note that most of these changes are expressed in early relapsed-remitting phase of the disease, even if there is no significant clinical correlation, while some pathologic features are characteristic of the progressive stage of the disease. This refers to subpial cortical pathology, which implies the formation of ectopic B cell follicles in the intrameningeal compartments, and is associated with aggressive course of the disease and rapid development of patient disability (Fig. 10).

\section{Dual Concept of Multiple Sclerosis Pathogenesis: Inflammation and Neurodegeneration}

The traditional belief of MS as an inflammatory demyelinating disease driven by an autoimmune process increasingly opposes the theory that MS is actually a neurodegenerative disease, either primary or age-related. Studies show support for both scenarios; therefore, dual concept of MS pathogenesis is the most acceptable theory, according to which MS is actually a biphasic disease, with a relapsing potentially reversible phase of disease that correlates with inflammatory demyelination, and secondary potentially irreversible phase of disease characterized by critical axonal loss. Inflammatory changes are less pronounced in later stage, although the disease is showing increasing progression. This dissociation between the intensity of inflammation and progressive development of neurological disability is an inflammation-neurodegenerative paradox characteristic of MS and indicates transition to the irreversible phase of the disease. Numerous clinical, neuropathological and neuroimaging studies have attempted to define the mutual association of 
inflammatory and progressive MS phases. It has long been known that early relapses affect long-term disability in MS, but there are still doubts and ambiguities what are the triggers for conversion of the relapsing remitting MS into the secondary progressive form. Some MS epidemiological studies have shown certain limitations to the influence of the inflammatory phase of the disease on the progression of disability, stating that the relapsing and neurodegenerative phases of MS are mutually independent. The predictive value of disability development, in addition to the number of relapses, may also have the age, sex, residual deficit after the first relapse, time to second relapse and total number of relapses in the first two years, and the duration of remission between relapses ${ }^{16-19}$. Although the impact of relapses on progression is controversial, MS ultimately results in unsustainable progressive phase with permanent disability of the patient ${ }^{20}$. The dual concept of the pathogenesis of MS essentially determines the beginning of treatment. In the secondary progressive form, therapeutic options are exhausted and reduced only to symptomatic treatment. Therefore, it is therapeutic imperative to act at an early stage of the disease and prevent conversion to the secondary progressive form, which is characterized by permanent disability of the patient (Fig. 11).

\section{References}

1. Matsui M. Multiple sclerosis immunology for clinicians. Neurol Asia. 2008;13:195-8.

2. Prat E, Martin R. The immunopathogenesis of multiple sclerosis. J Rehabil Res Dev. 2002 Apr;39(2):187-99.

3. Sospedra M, Martin R. Immunology of multiple sclerosis. Annu Rev Immunol. 2005 Apr;23(1):683-747. https://doi. org/10.1146/annurev.immunol.23.021704.115707

4. Henderson APD, Barnett MH, Parratt JDE, Prineas JW. Multiple sclerosis: distribution of inflammatory cells in newly forming lesions. Ann Neurol. 2009 Dec;66(6):739-53. https:// doi.org/10.1002/ana.21800

5. Lohr J, Knoechel B, Caretto D, Abbas AK. Balance of Th1 and Th17 effector and peripheral regulatory $\mathrm{T}$ cells. Microbes Infect. 2009 Apr;11(5):589-93. https://doi.org/10.1016/j. micinf.2009.04.012

6. Louten J, Boniface K, de Waal Malefyt R. Development and function of TH17 cells in health and disease. J Allergy Clin Immunol. 2009 May;123(5):1004-11. https://doi.org/10.1016/j.jaci.2009.04.003

7. Stromnes IM, Cerretti LM, Liggitt D, Harris RA, Goverman JM. Differential regulation of central nervous system autoim- munity by TH1 and TH17 cells. Nat Med. 2008 Mar;14(3): 337-42. https://doi.org/10.1038/nm1715

8. Oukka M. Interplay between pathogenic Th17 and regulatory T cells. Ann Rheum Dis. 2007 Nov 1;66(Suppl 3):iii87-iii90. http://dx.doi.org/10.1136/ard.2007.078527

9. Dalakas MC. B cells as therapeutic targets in autoimmune neurological disorders. Nat Clin Pract Neurol. 2008 Oct;4 (10):557-67. https://doi.org/10.1038/ncpneuro0901

10. Parkin J, Cohen B. An overview of the immune system. Lancet. 2001 Jun;357(9270):1777-89. https://doi.org/10.1016/S01406736(00)04904-7

11. Crawford A, Macleod M, Schumacher T, Corlett L, Gray D. Primary $\mathrm{T}$ cell expansion and differentiation in vivo requires antigen presentation by B cells. J Immunol Baltim Md 1950. 2006 Mar 15;176(6):3498-506.

12. Bar-Or A, Fawaz L, Fan B, Darlington PJ, Rieger A, Ghorayeb $\mathrm{C}$, et al. Abnormal B-cell cytokine responses a trigger of T-cellmediated disease in MS? Ann Neurol. 2010 Apr;67(4):452-61. https://doi.org/10.1002/ana.21939

13. Duddy M, Niino M, Adatia F, Hebert S, Freedman M, Atkins $\mathrm{H}$, et al. Distinct effector cytokine profiles of memory and naive human B cell subsets and implication in multiple sclerosis. J Immunol Baltim Md 1950. 2007 May 15;178(10):6092-9.

14. Serafini B, Rosicarelli B, Magliozzi R, Stigliano E, Aloisi F. Detection of ectopic B-cell follicles with germinal centers in the meninges of patients with secondary progressive multiple sclerosis. Brain Pathol Zurich Switz. 2004 Apr;14(2):164-74.

15. Magliozzi R, Howell OW, Reeves C, Roncaroli F, Nicholas R, Serafini $\mathrm{B}$, et al. A gradient of neuronal loss and meningeal inflammation in multiple sclerosis. Ann Neurol. 2010 Oct;68(4): 477-93. https://doi.org/10.1002/ana.22230

16. Weinshenker BG, Rice GP, Noseworthy JH, Carriere W, Baskerville J, Ebers GC. The natural history of multiple sclerosis: a geographically based study. 3. Multivariate analysis of predictive factors and models of outcome. Brain J Neurol. 1991 Apr;114 (Pt 2):1045-56.

17. Leray E, Yaouanq J, Le Page E, Coustans M, Laplaud D, Oger $\mathrm{J}$, et al. Evidence for a two-stage disability progression in multiple sclerosis. Brain. 2010 Jul 1;133(7):1900-13. https://doi.org/10.1093/brain/awq076

18. Confavreux C, Vukusic S. Natural history of multiple sclerosis: a unifying concept. Brain. 2006 Mar 1;129(3):606-16. https://doi.org/10.1093/brain/aw1007

19. Confavreux C, Vukusic S, Moreau T, Adeleine P. Relapses and progression of disability in multiple sclerosis. N Engl J Med. 2000 Nov 16;343(20):1430-8. https://doi.org/10.1056/NEJM200011163432001

20. Scalfari A, Neuhaus A, Degenhardt A, Rice GP, Muraro PA, Daumer M, et al. The natural history of multiple sclerosis, a geographically based study 10: relapses and long-term disability. Brain. 2010 Jul;133(7):1914-29. https://doi.org/10.1093/brain/awq118 
Sažetak

\section{MULTIPLA SKLEROZA: NOVI ASPEKT IMUNOPATOGENEZE}

\section{Lazibat, M. Rubinič Majdak i S. Županić}

Multipla skleroza (MS) je multikomponentna bolest koju karakterizira upala, neurodegeneracija i otkazivanje mehanizama za obnavljanje središnjega živčanog sustava. Uzrok MS još uvijek je nepoznat, ali je nedvojbeno da su genetski, okolišni i imuni čimbenici uključeni u etiopatogenezu ove složene i heterogene bolesti. S aspekta imunopatogeneze, donedavno je prevladavalo mišljenje da glavnu ulogu imaju autoreaktivni T limfociti aktiviranje kojih predstavlja ključni korak u nastanku MS. Saznanja o efektorskim i regulatornim ulogama B stanica podupiru novi koncept imunopatogeneze MS koji se temelji na vrlo kompleksnoj interakciji T i B stanica, s tim da B stanice aktivno sudjeluju u staničnoj imunosti tako što usmjeravaju intenzitet i kvalitetu staničnog imunog odgovora. Mehanizmi djelovanja B stanica u imunopatogenezi MS su višestruki te uključuju prezentaciju antigena i kostimulaciju $\mathrm{T}$ stanica, lučenje citokina, sintezu protutijela i formiranje ektopičnih limfoidnih B staničnih agregata $u$ intrameningealnim prostorima. Značenje B stanica u imunopatogenezi MS potvrđuju i suvremene terapijske opcije za liječenje MS.

Ključne riječi: multipla skleroza; upala; T-limfociti; B-limfociti; imunost, stanična 